$$
\begin{gathered}
\text { 일부 치과의사의 구강보건보조인력 활용과 업무에 관한 조사 } \\
\text { 박소영 } 1 \text {, 원영순 }{ }^{1} \text {, 김정숙 }{ }^{2}
\end{gathered}
$$

${ }^{1}$ 벽성대학 치위생과, ${ }^{2}$ 충북보건과학대학교 치위생과

\title{
Use and Work Scope of Oral Health Assistance Personnel as Perceived by Dentists
}

\author{
So-Young Park ${ }^{1} \neq$, Young-Soon Won ${ }^{1}$, Jeong-Suk Kim ${ }^{2}$ \\ ${ }^{1}$ Department of Dental Hygiene, Byucksung College, \\ 2Department of Dental Hygiene, Chungbuk health\&science University
}

\begin{abstract}
$<$ Abstract $>$
The objective of this study was to identify the current status of use and respective work scopes of dental hygienists and nursing assistants as perceived by dentists, thereby obtaining a model for how to efficiently use oral health assistance personnel. This study was based on a self-reported survey administered to a total of 126 dentists. The following findings were observed. Where competition among neighborhood clinics was relatively high, nursing assistants tended to be used as a resource to assist dental hygienists, whereas where it was relatively low, they were more likely to be considered to work as full substitutes for regular dental hygienists. Looking at the scopes of practice, dental hygienists were allowed to deal with matters of preventive care, oral health education, and health insurance claims. On the other hand, nursing assistants were allowed to be in charge of taking X-ray pictures from the outside and inside of mouth and keeping medical devices clean and safe. This study is expected to contribute to establishing more reasonable oral heath personnel structure design decisions.
\end{abstract}

Key Words : Dental Hygienist, Dentist, Nursing-Assistants, Work 


\section{I. 서론}

사회의 문화가 변화되고 다양해짐에 따라 건강 에 대한 요구와 관심이 증가되고 있으며, 이를 충 족시키기 위한 치과 의료계 역할의 다양성과 함께 그 기능도 수요자의 옥구를 충족시키기 위해 과거 에 보다 세분화 되어 가고 있는 추세이다. 또한 인 구의 증가와 고령화, 급속한 도시화와 산업화, 의 료보장제도의 확립 및 정부지원의 증가에 따른 공 공의료 서비스의 부문도 더욱 확대되어 가고 있다. 이러한 사회적 상황과 국민의 인식변화는 건강유 지를 위한 관심의 영역을 확대시켜 마침내 구강건 강의 중요성이 부각되기 시작하였다[1].

구강질환은 흔히 많은 사람들이 가지고 있는 만 성질환이다. 보건복지부가 2010년 발표한 국민영양 조사에 다르면 성인 중 $22.9 \%$ 는 치주질환을 겪고 있고, 2010년 건강보험심사평가원이 발표한 다빈도 상병 순위에서도 치주질환(3위)과 치아우식증(5위) 은 높은 순위를 차지하여 국민대다수의 구강건강 을 위협하는 질병이다[2].

국민의 구강질환 유병률 감소를 위해 의료서비 스를 전달하는 인력간의 체계적인 구조와 구강건 강 증진을 위해서는 구강병에 대한 적절한 관리와 함께 양질의 구강보건의료서비스를 생산, 제공할 수 있는 인력 및 업무시스템의 구축이 필요하며 [3], 이러한 구강보건인력자원의 활용이 의료의 질 과 병원 경영에 중요한 요소로 작용하게 될 것이 다[4].

치과 의료가 고도화됨에 따라 구강건강의식과 제도 및 자원을 적절히 개발시켜 구강건강을 원활 히 발전시켜야 할 필요성이 커지고 있다. 국민구강 보건의 발전을 위한 구강보건인력자원의 적절한 활용이 요구되며[5], 이러한 전문 인력의 구성에는 치과의사가 구강보건관리를 담당하며, 진료 분담 구강보건보조에는 치과위생사, 진료비분담 구강보 건보조는 간호사와 간호조무사 인력을 활용하고
있다[6].

구강보건보조인력 중 치과위생사는 1913년 미국 에서 그 당시 예방과 교육 및 공중구강보건사업의 중요성이 대두되면서 치과위생사제도가 시작되었 다[7]. 치과의사만으로는 이 사업을 수행하기에 역 부족임을 깨닫고 이를 위해 치과위생사 제도가 설 립되었으나, 그제도가 일본을 거쳐 1965년에 우리 나라에 도입되면서 그 당시 우리나라의 여건상 공 중구강보건업무와 내용 그리고 역할 등이 확립되 어 있지 않은 상태였기에 치과위생사는 본래의 업 무에 종사하기 힘들었으며, 차선책으로 구강진료보 조업무를 담당하였기에 그 후부터 지금까지 구강 진료실내의 진료보조자로서 업무수행을 주로 담당 해오게 되었던 실정이다[1].

치과위생사는 의료기사 등에 관한 법률 법 시행 령 제 2 조를 근거로 치석제거 및 치아 우식증의 예 방을 위한 불소도포 기타 치아 및 구강질환의 예 방과 위생에 관한 업무에 종사한다. 이 경우 의료 법 제 32 조의 2 제 1 항의 규정에 의한 안전관리 기준 에 적합하게 진단용 방사선발생장치를 설치한 보 건기관 또는 의료기관에서 구내진단용 방사선촬영 업무를 할 수 있다[8]. 이와는 달리 간호조무사는 간호조무사 및 의료유사업자에 관한 규칙 제 2 조에 의해 간호업무 보조에 관한 업무와 진료보조에 관 한 업무를 담당할 수 있다[9].

이러한 법적 명시에도 불구하고 김 등[10] 연구 에서의 치과위생사 업무 중 진료 협조의 업무 (59.1\%)가 가장 높았고, 예방치과처치의 업무(5.8\%) 는 가장 낮게 수행한다는 보고와 같이 아직까지도 치과의사는 치과위생사가 진료보조의 업무직군이 라는 인식이 강하다[11]. 이로 인해 치과위생사의 고유의 업무인 예방업무와 구강보건교육은 다소 등한시되어 치과위생사는 대학의 교육과정에서 배 운 전문적인 직업의식에 큰 혼란이 야기되었으며 정체성을 잃게 되고 임상에서의 근무가 장기간 이 루어지지 않아 실질적으로 활동하는 치과위생사의 
수는 매우 낮은 실정이다[12].

구강건강에 대한 국민의 수요가 늘어남에 따라 치과의료기관의 수가 증가하고 자연스럽게 구강보 건지식을 갖춘 전문적인 인력이 필요로 하게 되었 다. 치과의사의 수급 증가는 치과위생사의 수급 증 가와 맞물리고 치과위생사의 수급 증가로도 부족 한 구강보건보조인력의 빈 자리는 치과전문 간호 조무사의 양성으로 이어지고 있다. 구강보건보조인 력의 직군별 명확한 업무구분이 없이 혼재되어 있 는 치과 의료계는 전문직으로 본연의 업무를 수행 해야하는 치과위생사의 직업 수명을 단축시키는 등의 부작용을 초래하였다. 이는 임상현장에서 활 동하는 치과위생사 수의 저하와 구강 진료의 질을 낮추는 큰 부작용을 초래하게 될 것이다[8].

급변하는 사회적 변화에 발맞춰 치과 의료계도 치과위생사의 역할에 대한 새로운 변화를 요구하 고 있다. 즉 의료시장의 개방 등 공급 과잉현상으 로 치과의료기관간의 경쟁이 심해지고 소비자들의 의료서비스 질에 대한 요구도가 높아짐으로 인해 치과위생사의 역할 확립, 새로운 업무개발, 전문가 적인 수준의 업무 향상 등을 요구하고 있다. 의학 의 발달과 함께 생활수준이 향상된 국민들은 과거 에는 치료를 중심으로 초점을 맞추어 진료를 해 왔으나 현재는 치과계의 흐름이 구강병이 생기기 전에 예방을 하는 예방의학에 중점을 두어 치과진 료가 이루어지고 있다. 그리고 치의학분야에서도 예방치과처치 업무의 중요성이 더욱 강조되고 있 으며, 구강질환의 예방업무 전문가인 치과위생사가 변화하는 의료 환경에 맞는 역할을 수행하고 있는 지를 모색해 보는 것은 중요한 문제라고 할 수 있 다.

이에 본 연구에서는 치과의사가 근무하는 병원 의 여건별 치과위생사와 간호조무사의 활용에 대 해 알아보고 이들에게 수행하도록 하는 업무 범위 를 파악하여 구강보건보조인력의 효율적인 활용방 안을 위한 기초자료를 제공하고자 실시하였다.

\section{П. 연구대상 및 방법}

1. 연구대상

연구대상은 전라북도 지역에 있는 개인 치과병 (의)원, 공동개원 치과병(의)원, 네트워크형 치과병 (의)원, 종합(대학)병원에 근무하는 치과의사 150 명 에게 설문지를 배부하여 그 중 141 부를 회수하였 으며, 설문지 중 응답이 불성실하거나 응답요령을 숙지하지 못하였다고 판단된 설문지 15 부를 제외 하고 126 부의 설문지를 분석하였다.

\section{2. 연구내용 및 방법}

조사방법은 자기기입식 설문조사법으로, 2011년 9월 18 일부터 10 월 17 일까지 직접 개별적으로 배 포하여 수거하였다.

설문문항은 임상에서의 치과위생사 수행업무를 중심으로 작성된 직무기술서[13]와 박[14] 등이 2004년 치과위생사의 업무확장에 관한 조사연구에 서 사용한 항목을 기초로 하여 수정-보완한 설문 지를 사용하였다.

조사의 내용은 '성별', '연령', '면허취득한 시기', '병원형태', '직무분주도', '최근 6개월간 일일 환자 수', '치과의사수', '같은 연령대의 치과의사와 비교 시 수입정도', '인근 치과진료기관 경쟁정도' 등 인 구통계학적 변수 9개 항목, 치과위생사와 간호조무 사의 업무 범위 변수 15 개 항목, '병원 근무여건에 따른 치과위생사의 인원', '병원 근무여건에 따른 간호조무사의 인원', '간호조무사의 활용 방식', '간 호조무사의 채용이유', '치과위생사와 간호조무사의 업무분담에 대한 인식' 등으로 구성하였다.

그 중 치과의사가 수긍하는 치과위생사와 간호 조무사의 업무범위에서는 '예진 및 상담의 업무' 2 개 항목, '예방치과 처치의 업무' 3 개 항목, '구강보 건교육의 업무' 3 개 항목, '치과진료협조 및 방사선 
촬영'의 업무 4 개 항목, '병원 행정·보험 청구'의 업무 3 개 항목 등 각각 5 개의 하부영역으로 구성 하였다. 또한 각 조사 항목에 대하여 시술내용을 '치과위생사에게 업무수긍', '간호조무사에게 업무 수긍', '두 집단 모두 수긍 안한다', '두 집단 모두 수긍 한다' 로 4 단계 응답 중 선택할 수 있도록 설 문지를 구성하였다.

또한 치과위생사와 간호조무사의 업무분담 지각 도를 파악하기 위해 15 가지 업무들의 수긍 여부에 대한 빈도를 산출하였으며, 두 직군 모두에게 업무 를 수긍하지 않는 경우에는 치과의사가 직접 시술 하는 것으로 간주하여 산출하였다.

\section{3. 통계분석}

수집된 자료는 SPSS(SPSS 17.0 for Windows, SPSS Inc, USA)를 이용하여 분석하였다. 연구대상 자의 인구통계학적특성과 구강보건보조인력 업무 수긍 범위는 빈도와 백분율을 산출하였고, '병원 근무여건에 따른 치과위생사의 인원', '병원 근무여 건에 따른 간호조무사의 인원', '간호조무사의 활용 방식', '간호조무사의 채용이유' 등의 차이는 집단 간의 차이검정인 교차분석을 실시하였다. 연구의 실증분석은 $\mathrm{p}<0.05, \mathrm{p}<0.01, \mathrm{p}<0.001$ 에서 검정하였 다.

치과위생사와 간호조무사의 업무분담 지각도를 분석하고자 치과의사가 인지하는 대상들 간의 관 련된 관계를 다차원 공간에서 단순한 구도로 시각 화하여 보여주는 다차원 척도법(Multidimensional Scaling: MDS)을 통해 파악하였다. 이는 치과진료 의 업무별 근접한 속성들을 식별하기 위해 대응일 치분석을 이용하였다.

\section{III. 연구결과}

연구대상자의 성별은 남자가 $94(74.6 \%)$ 명으로 여자보다 더 많았으며, 연령별로는 30대 이하가 $54(42.9 \%)$ 명으로 가장 많았다. 면허취득한 시기는 1991년에서 2000년에 취득한 응답자가 56(44.4\%)명 으로 가장 많았으며, 근무하는 병원의 형태는 개인 치과가 $87(69.0 \%)$ 명으로 가장 많았다. 함께 근무하 는 치과의사의 수는 1명이 $79(62.7 \%)$ 명으로 가장 많았으며, 인근 치과진료기관의 경쟁정도는 높은편 이 94(74.6\%)명으로 가장 많이 나타났다<표 1>.

<표 1> 연구대상자의 일반적 특성

\begin{tabular}{|c|c|c|c|}
\hline 특성 & 구분 & $\mathrm{N}$ & $\%$ \\
\hline \multirow{2}{*}{ 성별 } & 남자 & 94 & 74.6 \\
\hline & 여자 & 32 & 25.4 \\
\hline \multirow{3}{*}{ 연령(개방형질문) } & 30대 이하 & 54 & 42.8 \\
\hline & 40대 & 53 & 42.1 \\
\hline & 50대 이상 & 19 & 15.1 \\
\hline \multirow{3}{*}{$\begin{array}{l}\text { 면허취득한 시기 } \\
\text { (개방형질문) }\end{array}$} & 1990년 이하 & 37 & 29.4 \\
\hline & 1991년-2000년 & 56 & 44.4 \\
\hline & 2001년 이상 & 33 & 26.2 \\
\hline \multirow{4}{*}{ 병원형태 } & 개인치과 & 87 & 69.0 \\
\hline & 공동개원 & 19 & 15.2 \\
\hline & 네트워크 & 10 & 7.9 \\
\hline & 종합병원 & 10 & 7.9 \\
\hline \multirow{2}{*}{ 직무분주도 } & 분주하지않다 & 55 & 43.7 \\
\hline & 분주하다 & 71 & 56.3 \\
\hline \multirow{3}{*}{$\begin{array}{l}\text { 최근 6개월간 } \\
\text { 일일 환자수 }\end{array}$} & 20명대 이하 & 39 & 31.0 \\
\hline & 30명대 & 54 & 42.9 \\
\hline & 40명대 이상 & 33 & 26.1 \\
\hline \multirow{3}{*}{ 치과의사수 } & 1명 & 79 & 62.7 \\
\hline & 2명 & 21 & 16.7 \\
\hline & 3명 이상 & 26 & 20.6 \\
\hline \multirow{2}{*}{ 수입정도 } & 많은편 & 65 & 51.6 \\
\hline & 적은편 & 61 & 48.4 \\
\hline \multirow{3}{*}{$\begin{array}{l}\text { 인근 치과진료기관 } \\
\text { 경쟁정도 }\end{array}$} & 높은편 & 94 & 74.6 \\
\hline & 낮은편 & 32 & 25.4 \\
\hline & 합계 & 126 & 100 \\
\hline
\end{tabular}

1. 연구대상자의 일반적 특성 
2. 치과의사의 근무여건별 치과위생사 인원

연구대상자의 근무여건에 따른 치과위생사 인원 에서는 '병원형태', '직무분주도', '일일 환자의 수', '의사의 수', '경쟁정도'에 따라 차이가 있었으며 분석결과는 <표 2>와 같다. '병원형태'에 따른 치 과위생사 수는 '개인·공동병원'에서 1 인, '네트워크. 종합병원'에서는 7 인 이상이 가장 많았다 $(\mathrm{p}<0.01)$. '직무분주도가 낮음'에서는 1 인이 많았으며, '직무 분주도가 높음'에서는 $4 \sim 6$ 인이 가장 많았다 $(\mathrm{p}<0.05)$. '일일 환자수가 35 명 미만'인 경우 1 인의 근무가 많은데 비해 '일일환자수가 35명 이상'인 경우에는 7 인 이상이 많았다 $(\mathrm{p}<0.01)$. '의사 1 인'에 서는 치과위생사가 없는 경우가 많았으나, '의사 2 인 이상'에서는 7 인 이상이 많았다( $\mathrm{p}<0.01)$. 인근병 원들의 '경쟁정도 높음'에는 2 3인이 근무하는 경 우가 많았으나, '경쟁정도 낮음'에는 치과위생사가 없는 경우가 많았다 $(\mathrm{p}<0.05)$.

\section{3. 치과의사의 근무여건별 간호조무사 인원}

연구대상자의 근무여건에 따른 간호조무사의 인 원에서는 '병원형태', '일일 환자의 수', '의사의 수', '경쟁정도'에 따라 차이가 있었으며 분석결과 는 <표 3>과 같다. '병원형태'에 따른 간호조무사 수는 '개인·공동병원'은 1 인이나 2 3인을 고용하는 경우가 많은데 비해, '네트워크·종합병원'에서는 7 인 이상이 가장 많았다 $(\mathrm{p}<0.01)$. '일일환자수가 35 명 미만'에서는 1 인을 채용한 경우가 가장 많았으
며, '일일환자수가 35 명 이상'에서는 7인 이상이 가 장 많았다 $(\mathrm{p}<0.01)$. '의사 1 인'인 경우에는 간호조 무사도 1 인인 경우가 많았으며, '의사 2 인 이상'인 경우에는 7인 이상을 채용한 경우가 많았다 $(\mathrm{p}<0.01)$. 인근병원들의 '경쟁정도 높음'에는 1 인이 채용과 간호조무사가 없는 경우가 많았으며, '경쟁 정도 낮음'에는 4 6인 이상이 근무하는 경우가 많 았다 $(\mathrm{p}<0.05)$.

4. 치과의사의 근무여건별 간호조무사 활용

연구대상자의 근무여건에 따른 간호조무사 활용 에서는 '경쟁정도'에 따라 차이가 있었으며 분석결 과는 <표 4 >와 같다. 인근 병원과 '경쟁정도 높음' 의 경우 치과위생사의 보조인력이나 진료협조의 업무 담당인력으로 활용되는 경우가 가장 많았으 며, '경쟁정도 낮음'의 경우 치과위생사의 대체인력 으로 활용되는 경우가 가장 많았다( $\mathrm{p}<0.05)$.

5. 치과의사의 근무여건별 간호조무사 채용이유

연구대상자의 근무여건에 따른 간호조무사 채용 이유에는 ‘병원형태'에 따라 차이가 있었으며 분석 결과는 <표 5>와 같다. 병원형태별로는 '개인·공동 병원'의 경우 치과위생사 채용이 어렵기 때문에 채 용한다가 가장 많은데 비해, '네트워크·종합병원'의 경우 치과위생사 인건비 부담으로 인해 채용한다 가 가장 많았다 $(\mathrm{p}<0.05)$. 
<표 2> 치과의사의 근무여건별 치과위생사 인원

\begin{tabular}{|c|c|c|c|c|c|c|c|c|c|c|c|c|c|c|c|}
\hline & \multicolumn{3}{|c|}{ 병원형태 } & \multicolumn{3}{|c|}{ 직무분주도 } & \multicolumn{3}{|c|}{ 일일환자수 } & \multicolumn{3}{|c|}{ 의사수 } & \multicolumn{3}{|c|}{ 경쟁정도 } \\
\hline & $\begin{array}{l}\text { 개인 } \\
\text { 공동 }\end{array}$ & $\begin{array}{l}\text { 네트 } \\
\text { 종합 }\end{array}$ & $\begin{array}{l}\chi^{2} \\
(p)\end{array}$ & 낮음 & 높음 & $\begin{array}{l}\chi^{2} \\
(p)\end{array}$ & $\begin{array}{l}35 \text { 명 } \\
\text { 미만 }\end{array}$ & $\begin{array}{l}35 \text { 명 } \\
\text { 이상 }\end{array}$ & $\begin{array}{l}\chi^{2} \\
\text { (p) }\end{array}$ & 1인 & $\begin{array}{l}\text { 2인 } \\
\text { 이상 }\end{array}$ & $\begin{array}{l}\chi^{2} \\
\text { (p) }\end{array}$ & 높음 & 낮음 & $\begin{array}{l}\chi^{2} \\
(p)\end{array}$ \\
\hline 없음 & $\begin{array}{r}5 \\
(100.0)\end{array}$ & $\begin{array}{r}0 \\
(0.0)\end{array}$ & & $\begin{array}{r}2 \\
(40.0)\end{array}$ & $\begin{array}{r}3 \\
(60.0)\end{array}$ & & $\begin{array}{r}3 \\
(60.0)\end{array}$ & $\begin{array}{r}2 \\
(40.0)\end{array}$ & & $\begin{array}{r}4 \\
(80.0)\end{array}$ & $\begin{array}{r}1 \\
(20.0)\end{array}$ & & $\begin{array}{r}2 \\
(40.0)\end{array}$ & $\begin{array}{r}3 \\
(60.0)\end{array}$ & \\
\hline 1인 & $\begin{array}{r}43 \\
(97.7)\end{array}$ & $\begin{array}{r}1 \\
(2.3)\end{array}$ & & $\begin{array}{r}27 \\
(61.4)\end{array}$ & $\begin{array}{r}17 \\
(38.6)\end{array}$ & & $\begin{array}{r}40 \\
(90.9)\end{array}$ & $\begin{array}{r}4 \\
(9.1)\end{array}$ & & $\begin{array}{r}35 \\
(79.5)\end{array}$ & $\begin{array}{r}9 \\
(20.5)\end{array}$ & & $\begin{array}{r}27 \\
(61.4)\end{array}$ & $\begin{array}{r}17 \\
(38.6)\end{array}$ & \\
\hline 2 3인 & $\begin{array}{r}39 \\
(90.7)\end{array}$ & $\begin{array}{r}4 \\
(9.3)\end{array}$ & $\begin{array}{r}39.53 \\
(0.00) \\
* *\end{array}$ & $\begin{array}{r}16 \\
(37.2)\end{array}$ & $\begin{array}{r}27 \\
(62.8)\end{array}$ & $\begin{array}{r}11.08 \\
(0.03) \\
\text { * }\end{array}$ & $\begin{array}{r}38 \\
(88.4)\end{array}$ & $\begin{array}{r}5 \\
(11.6)\end{array}$ & $\begin{array}{r}43.43 \\
(0.00) \\
\star \star *\end{array}$ & $\begin{array}{r}32 \\
(74.4)\end{array}$ & $\begin{array}{r}11 \\
(25.6)\end{array}$ & $\begin{array}{r}38.86 \\
(0.00) \\
* *\end{array}$ & $\begin{array}{r}37 \\
(86.0)\end{array}$ & $\begin{array}{r}6 \\
(14.0)\end{array}$ & $\begin{array}{l}11.28 \\
(0.02)\end{array}$ \\
\hline 4 6인 & $\begin{array}{r}13 \\
(76.5)\end{array}$ & $\begin{array}{r}4 \\
(23.5)\end{array}$ & & $\begin{array}{r}3 \\
(17.6)\end{array}$ & $\begin{array}{r}14 \\
(82.4)\end{array}$ & & $\begin{array}{r}9 \\
(52.9)\end{array}$ & $\begin{array}{r}8 \\
(47.1)\end{array}$ & & $\begin{array}{r}8 \\
(47.1)\end{array}$ & $\begin{array}{r}9 \\
(52.9)\end{array}$ & & $\begin{array}{r}14 \\
(82.4)\end{array}$ & $\begin{array}{r}3 \\
(17.6)\end{array}$ & \\
\hline 7인이상 & $\begin{array}{r}6 \\
(35.3)\end{array}$ & $\begin{array}{r}11 \\
(64.7)\end{array}$ & & $\begin{array}{r}7 \\
(41.2)\end{array}$ & $\begin{array}{r}10 \\
(58.8)\end{array}$ & & $\begin{array}{r}3 \\
(17.6)\end{array}$ & $\begin{array}{r}14 \\
(82.4)\end{array}$ & & $\begin{array}{r}0 \\
(0.0)\end{array}$ & $\begin{array}{r}17.0 \\
(100.0)\end{array}$ & & $\begin{array}{r}14 \\
(82.4)\end{array}$ & $\begin{array}{r}3 \\
(17.6)\end{array}$ & \\
\hline
\end{tabular}

셀 안의 수치는 관측빈도 및 퍼센트

* : $p<0.05$, ** : $p<0.01$

<표 3> 치과의사의 근무여건별 간호조무사 인원

\begin{tabular}{|c|c|c|c|c|c|c|c|c|c|c|c|c|c|c|c|}
\hline & \multicolumn{3}{|c|}{ 병원형태 } & \multicolumn{3}{|c|}{ 직무분주도 } & \multicolumn{3}{|c|}{ 일일환자수 } & \multicolumn{3}{|c|}{ 의사수 } & \multicolumn{3}{|c|}{ 경쟁정도 } \\
\hline & $\begin{array}{l}\text { 개인 } \\
\text { 공동 }\end{array}$ & $\begin{array}{l}\text { 네트 } \\
\text { 종합 }\end{array}$ & $\begin{array}{l}\chi^{2} \\
(p)\end{array}$ & 낮음 & 높음 & $\begin{array}{l}\chi^{2} \\
(p)\end{array}$ & $\begin{array}{l}35 \text { 명 } \\
\text { 미만 }\end{array}$ & $\begin{array}{l}35 \text { 명 } \\
\text { 이상 }\end{array}$ & $\begin{array}{l}\chi^{2} \\
(p)\end{array}$ & 1인 & $\begin{array}{l}\text { 2인 } \\
\text { 이상 }\end{array}$ & $\begin{array}{l}\chi^{2} \\
\text { (p) }\end{array}$ & 높음 & 낮음 & $\begin{array}{l}\chi^{2} \\
(p)\end{array}$ \\
\hline 없음 & $\begin{array}{r}31.0 \\
(86.1)\end{array}$ & $\begin{array}{r}5.0 \\
(13.9)\end{array}$ & & $\begin{array}{r}13.0 \\
(36.1)\end{array}$ & $\begin{array}{r}23.0 \\
(63.9)\end{array}$ & & $\begin{array}{r}25.0 \\
(69.4)\end{array}$ & $\begin{array}{r}11.0 \\
(30.6)\end{array}$ & & $\begin{array}{r}24.0 \\
(66.7)\end{array}$ & $\begin{array}{r}12.0 \\
(33.3)\end{array}$ & & $\begin{array}{r}31.0 \\
(86.1)\end{array}$ & $\begin{array}{r}5.0 \\
(13.9)\end{array}$ & \\
\hline 1인 & $\begin{array}{r}19.0 \\
(90.5)\end{array}$ & $\begin{array}{r}2.0 \\
(9.5)\end{array}$ & & $\begin{array}{r}13.0 \\
(61.9)\end{array}$ & $\begin{array}{r}8.0 \\
(38.1)\end{array}$ & & $\begin{array}{r}19.0 \\
(90.5)\end{array}$ & $\begin{array}{r}2.0 \\
(9.5)\end{array}$ & & $\begin{array}{r}16.0 \\
(76.2)\end{array}$ & $\begin{array}{r}5.0 \\
(23.8)\end{array}$ & & $\begin{array}{r}19.0 \\
(90.5)\end{array}$ & $\begin{array}{r}2.0 \\
(9.5)\end{array}$ & \\
\hline 2 3인 & $\begin{array}{r}48.0 \\
(88.9)\end{array}$ & $\begin{array}{r}6.0 \\
(11.1)\end{array}$ & $\begin{array}{r}28.28 \\
(0.00) \\
* *\end{array}$ & $\begin{array}{r}23.0 \\
(42.6)\end{array}$ & $\begin{array}{r}31.0 \\
(57.4)\end{array}$ & $\begin{array}{r}3.78 \\
(0.44)\end{array}$ & $\begin{array}{r}45.0 \\
(83.3)\end{array}$ & $\begin{array}{r}9.0 \\
(16.7)\end{array}$ & $\begin{array}{r}23.32 \\
(0.00) \\
\star *\end{array}$ & $\begin{array}{r}35.0 \\
(64.8)\end{array}$ & $\begin{array}{r}19.0 \\
(35.2)\end{array}$ & $\begin{array}{r}12.59 \\
(0.01) \\
\text { * }\end{array}$ & $\begin{array}{r}35.0 \\
(64.8)\end{array}$ & $\begin{array}{r}19.0 \\
(35.2)\end{array}$ & $\begin{array}{r}9.73 \\
(0.04)\end{array}$ \\
\hline 4 6인 & $\begin{array}{r}8.0 \\
(80.0)\end{array}$ & $\begin{array}{r}2.0 \\
(20.0)\end{array}$ & & $\begin{array}{r}4.0 \\
(40.0)\end{array}$ & $\begin{array}{r}6.0 \\
(60.0)\end{array}$ & & $\begin{array}{r}3.0 \\
(30.0)\end{array}$ & $\begin{array}{r}7.0 \\
(70.0)\end{array}$ & & $\begin{array}{r}4.0 \\
(40.0)\end{array}$ & $\begin{array}{r}6.0 \\
(60.0)\end{array}$ & & $\begin{array}{r}6.0 \\
(60.0)\end{array}$ & $\begin{array}{r}4.0 \\
(40.0)\end{array}$ & \\
\hline 7인이상 & $\begin{array}{r}0.0 \\
(0.0)\end{array}$ & $\begin{array}{r}5.0 \\
(100.0)\end{array}$ & & $\begin{array}{r}2.0 \\
(40.0)\end{array}$ & $\begin{array}{r}3.0 \\
(60.0)\end{array}$ & & $\begin{array}{r}1.0 \\
(20.0)\end{array}$ & $\begin{array}{r}4.0 \\
(80.0)\end{array}$ & & $\begin{array}{r}0.0 \\
(0.0)\end{array}$ & $\begin{array}{r}5.0 \\
(100.0)\end{array}$ & & $\begin{array}{r}3.0 \\
(60.0)\end{array}$ & $\begin{array}{r}2.0 \\
(40.0)\end{array}$ & \\
\hline
\end{tabular}

셀 안의 수치는 관측빈도 및 퍼센트

* : $p<0.05, * *: p<0.01$

<표 4> 치과의사의 근무여건별 간호조무사 활용

\begin{tabular}{|c|c|c|c|c|c|c|c|c|c|c|c|c|c|c|c|}
\hline & \multicolumn{3}{|c|}{ 병원형태 } & \multicolumn{3}{|c|}{ 직무분주도 } & \multicolumn{3}{|c|}{ 일일환자수 } & \multicolumn{3}{|c|}{ 의사수 } & \multicolumn{3}{|c|}{ 경쟁정도 } \\
\hline & $\begin{array}{l}\text { 개인 } \\
\text { 공동 }\end{array}$ & $\begin{array}{l}\text { 네트 } \\
\text { 종합 }\end{array}$ & $\begin{array}{l}\chi^{2} \\
(p)\end{array}$ & 낮음 & 높음 & $\begin{array}{l}\chi^{2} \\
\text { (p) }\end{array}$ & $\begin{array}{l}\text { 35명 } \\
\text { 미만 }\end{array}$ & $\begin{array}{l}\text { 35명 } \\
\text { 이상 }\end{array}$ & $\begin{array}{l}\chi^{2} \\
(p)\end{array}$ & 1인 & $\begin{array}{l}\text { 2인 } \\
\text { 이상 }\end{array}$ & $\begin{array}{l}\chi^{2} \\
(p)\end{array}$ & 높음 & 낮음 & $\begin{array}{l}\chi^{2} \\
(p)\end{array}$ \\
\hline $\begin{array}{l}\text { 치과위생사 } \\
\text { 보조 }\end{array}$ & $\begin{array}{r}25.0 \\
(75.8)\end{array}$ & $\begin{array}{r}8.0 \\
(24.2)\end{array}$ & & $\begin{array}{r}15.0 \\
(45.5)\end{array}$ & $\begin{array}{r}18.0 \\
(54.5)\end{array}$ & & $\begin{array}{r}26.0 \\
(78.8)\end{array}$ & $\begin{array}{r}7.0 \\
(21.2)\end{array}$ & & $\begin{array}{r}21.0 \\
(63.6)\end{array}$ & $\begin{array}{r}12.0 \\
(36.4)\end{array}$ & & $\begin{array}{r}26.0 \\
(78.8)\end{array}$ & $\begin{array}{r}7.0 \\
(21.2)\end{array}$ & \\
\hline 진료 협조 업무 & $\begin{array}{r}26.0 \\
(81.3)\end{array}$ & $\begin{array}{r}6.0 \\
(18.8)\end{array}$ & 6.02 & $\begin{array}{r}16.0 \\
(50.0)\end{array}$ & $\begin{array}{r}16.0 \\
(50.0)\end{array}$ & 0.60 & $\begin{array}{r}22.0 \\
(68.8)\end{array}$ & $\begin{array}{r}10.0 \\
(31.3)\end{array}$ & 0.99 & $\begin{array}{r}22.0 \\
(68.8)\end{array}$ & $\begin{array}{r}10.0 \\
(31.3)\end{array}$ & 2.10 & $\begin{array}{r}27.0 \\
(84.4)\end{array}$ & $\begin{array}{r}5.0 \\
(15.6)\end{array}$ & 8.46 \\
\hline $\begin{array}{l}\text { 치과위생사 } \\
\text { 대체 }\end{array}$ & $\begin{array}{r}29.0 \\
(96.7)\end{array}$ & $\begin{array}{r}1.0 \\
(3.3)\end{array}$ & $(0.11)$ & $\begin{array}{r}13.0 \\
(43.3)\end{array}$ & $\begin{array}{r}17.0 \\
(56.7)\end{array}$ & $(0.90)$ & $\begin{array}{r}23.0 \\
(76.7)\end{array}$ & $\begin{array}{r}7.0 \\
(23.3)\end{array}$ & $(0.81)$ & $\begin{array}{r}17.0 \\
(56.7)\end{array}$ & $\begin{array}{r}13.0 \\
(43.3)\end{array}$ & $(0.55)$ & $\begin{array}{r}16.0 \\
(53.3)\end{array}$ & $\begin{array}{r}14.0 \\
(46.7)\end{array}$ & \\
\hline $\begin{array}{l}\text { 기구소독만 } \\
\text { 담당 }\end{array}$ & $\begin{array}{r}5.0 \\
(71.4)\end{array}$ & $\begin{array}{r}2.0 \\
(28.6)\end{array}$ & & $\begin{array}{r}4.0 \\
(57.1)\end{array}$ & $\begin{array}{r}3.0 \\
(42.9)\end{array}$ & & $\begin{array}{r}5.0 \\
(71.4)\end{array}$ & $\begin{array}{r}2.0 \\
(28.6)\end{array}$ & & $\begin{array}{r}3.0 \\
(42.9)\end{array}$ & $\begin{array}{r}4.0 \\
(57.1)\end{array}$ & & $\begin{array}{r}5.0 \\
(71.4)\end{array}$ & $\begin{array}{r}2.0 \\
(28.6)\end{array}$ & \\
\hline
\end{tabular}


<표 5> 치과의사의 근무여건별 간호조무사 채용이유

\begin{tabular}{|c|c|c|c|c|c|c|c|c|c|c|c|c|c|c|c|}
\hline & \multicolumn{3}{|c|}{ 병원형태 } & \multicolumn{3}{|c|}{ 직무분주도 } & \multicolumn{3}{|c|}{ 일일환자수 } & \multicolumn{3}{|c|}{ 의사수 } & \multicolumn{3}{|c|}{ 경쟁정도 } \\
\hline & $\begin{array}{l}\text { 개인 } \\
\text { 공동 }\end{array}$ & $\begin{array}{l}\text { 네트 } \\
\text { 종합 }\end{array}$ & $\begin{array}{l}\chi^{2} \\
(p)\end{array}$ & 낮음 & 높음 & $\begin{array}{l}\chi^{2} \\
(p)\end{array}$ & $\begin{array}{l}\text { 35명 } \\
\text { 미만 }\end{array}$ & $\begin{array}{l}35 \text { 명 } \\
\text { 이상 }\end{array}$ & $\begin{array}{l}\chi^{2} \\
(p)\end{array}$ & 1인 & $\begin{array}{l}\text { 2인 } \\
\text { 이상 }\end{array}$ & $\begin{array}{l}\chi^{2} \\
(p)\end{array}$ & 높음 & 낮음 & $\begin{array}{l}\chi^{2} \\
(p)\end{array}$ \\
\hline $\begin{array}{l}\text { 치과위생사 } \\
\text { 채용 어려움 }\end{array}$ & $\begin{array}{r}55.0 \\
(94.8)\end{array}$ & $\begin{array}{r}3.0 \\
(5.2)\end{array}$ & & $\begin{array}{r}26.0 \\
(44.8)\end{array}$ & $\begin{array}{r}32.0 \\
(55.2)\end{array}$ & & $\begin{array}{r}47.0 \\
(81.0)\end{array}$ & $\begin{array}{r}11.0 \\
(19.0)\end{array}$ & & $\begin{array}{r}41.0 \\
(70.7)\end{array}$ & $\begin{array}{r}17.0 \\
(29.3)\end{array}$ & & $\begin{array}{r}43.0 \\
(74.1)\end{array}$ & $\begin{array}{r}15.0 \\
(25.9)\end{array}$ & \\
\hline $\begin{array}{l}\text { 치과위생사의 } \\
\text { 인건비 부담 }\end{array}$ & $\begin{array}{r}14.0 \\
(66.7)\end{array}$ & $\begin{array}{r}7.0 \\
(33.3)\end{array}$ & & $\begin{array}{r}10.0 \\
(47.6)\end{array}$ & $\begin{array}{r}11.0 \\
(52.4)\end{array}$ & & $\begin{array}{r}14.0 \\
(66.7)\end{array}$ & $\begin{array}{r}7.0 \\
(33.3)\end{array}$ & & $\begin{array}{r}10.0 \\
(47.6)\end{array}$ & $\begin{array}{r}11.0 \\
(52.4)\end{array}$ & & $\begin{array}{r}14.0 \\
(66.7)\end{array}$ & $\begin{array}{r}7.0 \\
(33.3)\end{array}$ & \\
\hline $\begin{array}{l}\text { 치과위생사의 } \\
\text { 비슷한 능력 }\end{array}$ & $\begin{array}{r}11.0 \\
(73.3)\end{array}$ & $\begin{array}{r}4.0 \\
(26.7)\end{array}$ & $\begin{array}{r}(0.01) \\
*\end{array}$ & $\begin{array}{r}8.0 \\
(53.3)\end{array}$ & $\begin{array}{r}7.0 \\
(46.7)\end{array}$ & $\begin{array}{r}0.63 \\
(0.89)\end{array}$ & $\begin{array}{r}9.0 \\
(60.0)\end{array}$ & $\begin{array}{r}6.0 \\
(40.0)\end{array}$ & $\begin{array}{r}6.16 \\
(0.10)\end{array}$ & $\begin{array}{r}7.0 \\
(46.7)\end{array}$ & $\begin{array}{r}8.0 \\
(53.3)\end{array}$ & $\begin{array}{r}6.89 \\
(0.08)\end{array}$ & $\begin{array}{r}11.0 \\
(73.3)\end{array}$ & $\begin{array}{r}4.0 \\
(26.7)\end{array}$ & $\begin{array}{r}1.16 \\
(0.76)\end{array}$ \\
\hline $\begin{array}{l}\text { 함께 일하기 } \\
\text { 편함 }\end{array}$ & $\begin{array}{r}6.0 \\
(85.7)\end{array}$ & $\begin{array}{r}1.0 \\
(14.3)\end{array}$ & & $\begin{array}{r}4.0 \\
(57.1)\end{array}$ & $\begin{array}{r}3.0 \\
(42.9)\end{array}$ & & $\begin{array}{r}7.0 \\
(100.0)\end{array}$ & $\begin{array}{r}0.0 \\
(0.0)\end{array}$ & & $\begin{array}{r}6.0 \\
(85.7)\end{array}$ & $\begin{array}{r}1.0 \\
(14.3)\end{array}$ & & $\begin{array}{r}4.0 \\
(57.1)\end{array}$ & $\begin{array}{r}3.0 \\
(42.9)\end{array}$ & \\
\hline
\end{tabular}

셀 안의 수치는 관측빈도와 퍼센트

* : $\mathrm{p}<0.05, * *: \mathrm{p}<0.01$

6. 치과의사의 구강보건보조인력 업무 수긍 범위

연구대상자의 구강보건보조인력 업무 수긍 범위 의 분석결과는 <표 6>과 같다. “예진 및 상담의 업무” 중 “전체적인 구강내의 현재 상태 파악'에서 는 치과위생사에게 $60.8 \%$, 간호조무사는 $0.8 \%$, '환 자의 치료계획 및 치료비용의 상담에서는 치과위 생사에게 $65.0 \%$, 간호조무사는 $2.4 \%$ 업무 수행하 도록 하였다.

“예방 진료의 업무” 중 '전문가 불소도포'에서는 치과위생사에게 $76.6 \%$, 간호조무사는 $1.6 \%$ 업무를 수행하도록 하였으며, '치석제거'에서는 치과위생사 에게 $78.4 \%$, 간호조무사는 $4.0 \%$, '치아 홈 메우기' 는 치과위생사에게 $72.0 \%$, 간호조무사는 $0.8 \%$ 업 무를 수행하도록 하였다.

“구강보건교육의 업무" 중 “전문가 잇솔질 방법 교육'에서는 치과위생사에게 $69.6 \%$, 간호조무사는 $3.2 \%$ 업무를 수행하도록 하였으며, '구강위생용품 사용법 교육'에서는 치과위생사에게 $61.1 \%$, 간호조 무사는 $5.6 \%$, '환자 보호자 교육'은 치과위생사에 게 $59.2 \%$, 간호조무사는 $6.4 \%$ 업무를 수행하도록 하였다.
“진료협조 및 방사선촬영의 업무” 중 “러버댐 장착 및 제거'에서는 치과위생사에게 $62.4 \%$, 간호 조무사는 $4.0 \%$ 업무를 수행하도록 하였으며, '임시 치아 제작'에서는 치과위생사에게 $60.0 \%$, 간호조무 사는 $4.8 \%$ 업무를 수행하도록 하였다. 또한 '미백 시술'은 치과위생사에게 $54.0 \%$, 간호조무사는 $1.6 \%$ 업무를 수행하도록 하였으며, '구강 내·외 방사선 촬영'은 치과위생사에게 $38.9 \%$, 간호조무사는 $10.3 \%$ 업무를 수행하도록 하였다.

“병원행정 및 보험청구의 업무” 중 “기구소독 및 관리'에서는 치과위생사에게 $30.2 \%$, 간호조무사 는 $11.1 \%$ 업무를 수행하도록 하였으며, '병원 마케 팅 및 홍보의 업무'에서는 치과위생사에게 $52.8 \%$, 간호조무사는 $5.6 \%$, '건강보험청구'는 치과위생사 에게 $73.0 \%$, 간호조무사는 $4.8 \%$ 업무를 수행하도 록 하였다.

7. 치과의사의 구강보건보조인력 업무분담 지 각도

연구대상자의 구강보건보조인력 업무분담에 대 한 지각도의 분석결과는 <표 7>, <그림 $1>$ 과 같 다. 다차원 척도법을 통한 지각도를 파악한 결과 
“진료협조 및 방사선촬영 업무” 중 '미백시술'은 치과의사가 직접 시술해야한다고 인지하고 있는 것으로 나타났다. 치과위생사는 "구강보건교육 업 무” 중 '구강위생용품 사용법 교육', '전문가 잇솔
질 방법 교육' 등을 담당해야 한다고 인지하였으 며, 간호조무사는 '기구소독 및 관리의 업무'를 주 로 담당해야 한다고 인지하였다.

<표 6> 치과의사의 구강보건보조인력 업무 수긍 범위

\begin{tabular}{|c|c|c|c|c|}
\hline \multirow{2}{*}{ 업무 } & \multicolumn{4}{|c|}{ 수긍 범위 } \\
\hline & 치과위생사 & 간호조무사 & 모두 불허 & 모두 수긍 \\
\hline \multicolumn{5}{|l|}{ <예진 및 상담 업무> } \\
\hline 전체적인 구강내의 상태 파악 & $\begin{array}{r}76 \\
(60.8)\end{array}$ & $\begin{array}{r}1 \\
(0.8)\end{array}$ & $\begin{array}{r}33 \\
(26.4)\end{array}$ & $\begin{array}{r}15 \\
(12.0)\end{array}$ \\
\hline 환자의 치료계획 및 비용 상담 & $\begin{array}{r}80 \\
(65.0)\end{array}$ & $\begin{array}{r}3 \\
(2.4)\end{array}$ & $\begin{array}{r}28 \\
(22.8)\end{array}$ & $\begin{array}{r}12 \\
(9.8)\end{array}$ \\
\hline \multicolumn{5}{|l|}{ <예방 진료 업무> } \\
\hline 전문가 불소도포 & $\begin{array}{r}95 \\
(76.6)\end{array}$ & $\begin{array}{r}2 \\
(1.6)\end{array}$ & $\begin{array}{r}14 \\
(11.3)\end{array}$ & $\begin{array}{r}13 \\
(10.5)\end{array}$ \\
\hline 치석제거 & $\begin{array}{r}98 \\
(78.4)\end{array}$ & $\begin{array}{r}5 \\
(4.0)\end{array}$ & $\begin{array}{r}1 \\
(0.8)\end{array}$ & $\begin{array}{r}21 \\
(16.8)\end{array}$ \\
\hline 치아 홈 메우기 & $\begin{array}{r}90 \\
(72.0)\end{array}$ & $\begin{array}{r}1 \\
(0.8)\end{array}$ & $\begin{array}{r}23 \\
(18.4)\end{array}$ & $\begin{array}{r}11 \\
(8.8)\end{array}$ \\
\hline \multicolumn{5}{|l|}{ <구강보건교육 업무> } \\
\hline 전문가 잇솔질 방법 교육 & $\begin{array}{r}87 \\
(69.6)\end{array}$ & $\begin{array}{r}4 \\
(3.2)\end{array}$ & $\begin{array}{r}5 \\
(4.0)\end{array}$ & $\begin{array}{r}29 \\
(23.2)\end{array}$ \\
\hline 구강위생용품 사용법 교육 & $\begin{array}{r}77 \\
(61.1)\end{array}$ & $\begin{array}{r}7 \\
(5.6)\end{array}$ & $\begin{array}{r}5 \\
(4.0)\end{array}$ & $\begin{array}{r}37 \\
(29.4)\end{array}$ \\
\hline 환자 보호자 교육 & $\begin{array}{r}74 \\
(59.2)\end{array}$ & $\begin{array}{r}8 \\
(6.4)\end{array}$ & $\begin{array}{r}8 \\
(6.4)\end{array}$ & $\begin{array}{r}35 \\
(28.0)\end{array}$ \\
\hline \multicolumn{5}{|l|}{ <진료협조 및 방사선촬영 업무> } \\
\hline 러버댐 장착 및 제거 & $\begin{array}{r}78 \\
(62.4)\end{array}$ & $\begin{array}{r}5 \\
(4.0)\end{array}$ & $\begin{array}{r}26 \\
(20.8)\end{array}$ & $\begin{array}{r}16 \\
(12.8)\end{array}$ \\
\hline 임시치아 제작 & $\begin{array}{r}75 \\
(60.0)\end{array}$ & $\begin{array}{r}6 \\
(4.8)\end{array}$ & $\begin{array}{r}8 \\
(6.4)\end{array}$ & $\begin{array}{r}36 \\
(28.8)\end{array}$ \\
\hline 미백 시술 & $\begin{array}{r}68 \\
(54.0)\end{array}$ & $\begin{array}{r}2 \\
(1.6)\end{array}$ & $\begin{array}{r}47 \\
(37.3)\end{array}$ & $\begin{array}{r}9 \\
(7.1)\end{array}$ \\
\hline 구강 내·외 방사선 촬영 & $\begin{array}{r}49 \\
(38.9)\end{array}$ & $\begin{array}{r}13 \\
(10.3)\end{array}$ & $\begin{array}{r}3 \\
(2.4)\end{array}$ & $\begin{array}{r}61 \\
(48.4)\end{array}$ \\
\hline \multicolumn{5}{|l|}{ <병원행정 및 보험청구 업무> } \\
\hline 기구소독 및 관리 & $\begin{array}{r}38 \\
(30.2)\end{array}$ & $\begin{array}{r}14 \\
(11.1)\end{array}$ & $\begin{array}{r}6 \\
(4.8)\end{array}$ & $\begin{array}{r}68 \\
(54.0)\end{array}$ \\
\hline 병원 마케팅 및 홍보의 업무 & $\begin{array}{r}66 \\
(52.8)\end{array}$ & $\begin{array}{r}7 \\
(5.6)\end{array}$ & $\begin{array}{r}15 \\
(12.0)\end{array}$ & $\begin{array}{r}37 \\
(29.6)\end{array}$ \\
\hline 건강보험청구 & $\begin{array}{r}92 \\
(73.0)\end{array}$ & $\begin{array}{r}6 \\
(4.8)\end{array}$ & $\begin{array}{r}6 \\
(4.8)\end{array}$ & $\begin{array}{r}22 \\
(17.5)\end{array}$ \\
\hline
\end{tabular}


<표 7> 구강보건보조인력의 업무분담에 대한 대응일치분석

\begin{tabular}{|c|c|c|c|}
\hline Configuration Point & Point Definition & Coordination X (Dim. 1) & Coordination Y (Dim. 2) \\
\hline$J 1$ & 구강상태파악 & -0.82 & 0.17 \\
\hline J2 & 방사선촬영 & 0.73 & 0.48 \\
\hline J3 & 치료계획비용상담 & -0.70 & 0.00 \\
\hline $\mathrm{J4}$ & 불소도포 & -0.24 & -0.56 \\
\hline$\sqrt{5}$ & 치석제거 & 0.32 & -0.71 \\
\hline$\sqrt{6}$ & 치아홈메우기 & -0.58 & -0.32 \\
\hline $\mathrm{J} 7$ & 러버댐장착제거 & -0.52 & 0.08 \\
\hline J8 & 임시치아제작 & 0.30 & -0.05 \\
\hline J9 & 미백시술 & -1.39 & 0.59 \\
\hline J10 & 잇솔질교육 & 0.28 & -0.38 \\
\hline J11 & 구강용품사용교육 & 0.41 & -0.10 \\
\hline$J 12$ & 환자보호자교육 & 0.32 & -0.01 \\
\hline J13 & 건강보험청구 & 0.20 & -0.47 \\
\hline$J 14$ & 기구소독관리 & 0.71 & 0.70 \\
\hline J15 & 병원마케팅홍보 & 0.13 & 0.23 \\
\hline $\mathrm{R} 1$ & 치과위생사 & 0.00 & -0.28 \\
\hline R2 & 간호조무사 & 0.71 & 0.59 \\
\hline R3 & 치과의사 & -1.55 & 0.61 \\
\hline \multicolumn{2}{|c|}{ Singular Value } & 0.35 & 0.17 \\
\hline \multicolumn{2}{|c|}{ 설명력 } & $0.81 \%$ & $0.19 \%$ \\
\hline
\end{tabular}

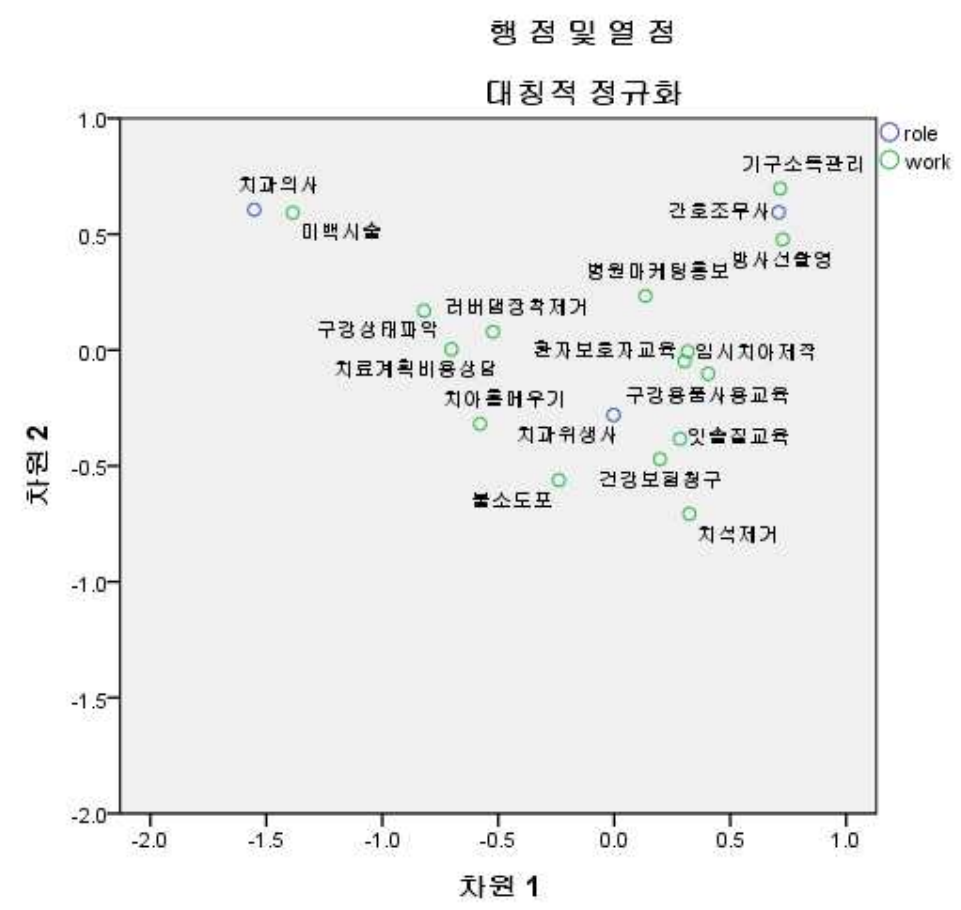

<그림 1> 구강보건보조인력의 업무분담 지각도 


\section{IV. 고찰 및 결론}

국민들의 구강건강에 대한 관심이 증가함에 따 라 치과의료기관의 수적 증가로 이루어졌고 자연 스럽게 구강보건인력의 양성이 필요하게 되었다. 치과의사의 수급 증가는 치과위생사의 수급 증가 와 맞물리고 치과위생사의 수급 증가로도 부족한 구강보건인력의 빈자리는 간호조무사 직군으로 채 워지게 되었으며, 전문성이 확보되지 않은 치과위 생사는 각각의 역할에 따른 명확한 업무구분이 없 는 임상현장에서 직업의 정체성에 대해 혼재를 느 낄 것이며 이는 치과위생사 직업의 수명을 단축시 키는 등의 부작용을 초래할 뿐 아니라 치과 의료 서비스의 질을 저하시키는 중요한 요소가 될 것이 다[10].

이에 본 연구는 현재 치과의료기관에서 근무하 는 치과의사들이 인식하는 구강보건보조인력 의 업무 수행범위와 적절한 활용 및 효율적인 업무를 지향하기 위하여 수행하였으며 그 결과에 대해 논 의해보고자 한다.

치과의사가 근무하는 치과의료기관이 인근 병원 과 경쟁정도가 높은 경우 간호조무사가 치과위생 사의 보조 인력이나 진료협조 업무 담당인력으로 활용되는 경우가 많았는데, 이는 임[15]의 연구와 일치하였다. 경쟁정도가 높은 치과의료기관에서는 정해진 시간에 효율적인 진료의 진행이 좀 더 요 구되므로 숙련된 치과의사와 이를 협조해주는 치 과위생사가 본연의 업무를 수행할 수 있도록 기타 보조적인 업무를 뒷받침 해줄 수 있는 인력의 수 요가 많을 것이라 사료된다. 상대적으로 경쟁정도 가 낮은 경우는 간호조무사를 치과위생사의 대체 인력으로 활용되는 경우가 많았는데, 내원환자가 적은 치과의료기관에서는 업무 분주도가 낮아 치 과위생사의 인력수급난이 더 심각하여 이를 대체 해 줄 인력의 수요가 더욱 많을 것이다.이는 김 [16]의 연구결과와 같이 치과위생사들이 대형치과
선호현상이 날로 심화되고 있기 때문이라 생각된 다. 이들이 대형치과를 선호하는 이유로는 적절한 급여의 제공과 근무환경개선 및 복지정책이 치과 의료기관의 규모가 클수록 좀 더 긍정적일 것이라 는 기대감 때문일 것이다. 이에 치과위생사의 채용 에 관한 여건별 임금 지급 기준의 권장 사항 등을 제안하여 치과규모별 불균형이 없도록 개선책을 마련해야 할 것이다.

간호조무사의 채용이유에서 개인·공동병원은 치 과위생사의 구인난으로 간호조무사를 채용하는 경 우가 많았고, 네트워크·종합병원은 치과위생사 인 건비 부담으로 인해 채용하는 경우가 많은 것으로 나타났는데, 이는 간호조무사를 채용하는 이유가 치과위생사를 채용하기 어려워 불가피한 차선책이 라는 연구결과와 유사하였다[15]. 2012년 치과 임 상가의 '진료분담인력 구인난'에 관한 보고에서 치 과위생사는 구인난이 $89.5 \%$ 에 달했고, 이는 2003년 의 $55.7 \%$ 보다 $30 \%$ 이상 상승하였다[17]. 치과위생사 의 인력양성 및 활발한 임상현장에서의 업무수행 을 위한 대책안이 요구되며 이러한 현실을 간과하 여 업무의 확실한 정립과 전문직으로서의 영역을 펼칠 수 있는 정책적인 뒷받침 또한 필요할 것이 다.

치과의사가 예방 진료 업무의 수긍범위에서 전 문가 불소도포와 치면열구전색은 주로 치과위생사 에게 수행하도록 한다는 결과가 나타났고, 이는 치 과의사를 대상으로 실시한 천[18]의 연구와 유사하 였다. 이 연구에서 치과의사들은 예방 진료 업무를 간호조무사에게 수행토록 하는 것은 시기상조이며, 정규의 교육과 숙련과정을 통하여 업무수긍여부를 결정해야 할 것이라 하였다. 1993년 선행연구인 정 [11]의 조사결과에서 치과위생사의 진료보조의 업 무 $72.7 \%$, 구강 보건 교육업무 $10.8 \%$, 예방치과 업 무 $9.1 \%$ 의 결과와 비교해 볼 때 치과의사들의 치 과위생사 고유의 업무에 대한 바람직한 인식이 확 립되어 가고 있다고 판단할 수 있으며, 이에 치과 
위생사는 명확한 업무 정착을 위해 전문적인 지식 과 기술을 훈련하고, 직업의 긍정적 인식 전환을 위해 끊임없이 노력해야 할 것이다.

또한 구강보건보조인력을 대상으로 조사한 안 [3]의 연구에서 실제로 치과위생사가 구강병 예방 업무를 $45 \%$ 정도 수행하며, 간호조무사는 $12 \%$ 를 수행한다는 연구결과와 같이 전문적인 지식과 기 술을 필요로 하는 예방 진료 업무는 치위생사의 법정업무로 정착시켜 의료서비스의 질 향상과 더 불어 구강병 예방과 환자관리 측면이 강조되어야 할 것이다.

이러한 우식예방을 위한 예방진료 업무는 치과 위생사의 법정업무로서 전문가 불소도포의 경우 불소의 성분, 취급방법, 사용법 등을 충분히 교육 과 임상훈련을 받은 치과위생사가 하는 것이 당연 하며, 치면열구전색 또한 전색 시 초기우식 판별 및 잘못된 시술로 이차우식을 유발할 수 있는 잘 못된 전색술등을 본연에 방지하기 위해 철저한 교 육과 숙련된 기술을 필요로 할 것이다.

구내·외 방사선 촬영업무에서는 간호조무사에게 많이 수행하도록 한다는 의견이 높았는데 이는 박 [19]의 연구결과인 치과의사들이 방사선 촬영업무 를 치과위생사에게만 수긍한다는 연구 결과와는 상반되었다. 치과위생사의 고유 업무 중 하나인 방 사선 촬영업무에 대한 인식이 미비한 결과이기도 하나 현 임상현장의 실정상 치과위생사의 인력 수 급이 심각하거나 내원환자가 많아 부득이 간호조 무사에게 방사선 촬영 교육을 실시 후 Cone을 맞 추는 행위까지를 허용한 후 촬영스위치를 누르는 행위는 치과의사나 치과위생사가 시행하여 진료의 효율을 높이는 경우도 있을 것이다. 그러나 이러한 업무 허용은 업무의 혼재를 일으킬 가능성이 크고, 특히 방사선 촬영은 기기에 대한 정확한 지식과 환자의 방사선 방어준비 등의 문제가 있으며 부정 적 방법을 시행하였을 시 법적인 문제가 맞물려 있기에 제재하는 것이 바람직하다.
미국을 비롯한 대부분 선진국에서도 치과진료조 무사(dental assistant)제도가 확립되어있으며, 치과 진료조무사 자격시험 시에 구강 내 방사선사진 촬 영 기술과 능력을 필기 또는 실기시험으로 평가하 는 국가들이 많으며, 이들 국가들에서는 치과진료 조무사에게 구강 내 방사선사진이나 파노라마 사 진 촬영을 허용함으로서 치과위생사는 주로 독자 적이고 전문적인 예방진료를 수행하며, 치과진료조 무사는 치과진료 시 진료 준비 업무 및 진료보조 업무와 방사선 사진촬영 등을 분담함으로서 보다 체계적이고 원활한 치과진료를 도모하고 있다.

이와 같이 구강보건보조인력의 활용과 업무에 대한 명확한 구분이 지향되어야 할 것이며, 치과위 생사 업무의 명확한 구분으로 고유 업무인 구강보 건교육 및 예방처치와 근무과별 특성에 따른 전문 화된 진료 협조, 전문화된 병원 행정 및 보험청구 등의 업무에 주력하고, 간호조무사는 진료협조의 업무를 담당하는 직종간의 업무분장이 이루어져야 할 것이다[15].

본 연구의 제한점으로는 연구 대상자가 일부의 지역 치과의사들을 대상으로 실시하여 모집단을 대표하기에는 다소 부족한 점이 있으나, 이를 토대 로 구강보건보조인력의 활용과 업무에 관한 논의 의 기초 자료를 제시하는 데는 그 의의가 있다고 하겠다.

최[20]의 연구에서 일반 병의원에 근무하는 간 호조무사의 업무에 대한 보고에서 간호사와의 업 무 구분에 있어서 명확한 한계 없이 수행되고 있 음을 지적하고 있는데, 치과에 근무하는 간호조무 사도 그와 비슷한 양상이며, 더 환기해야 할 점은 치과위생사가 구강병 예방을 위한 인력으로 활용 되기 위해서는 그들 스스로 업무에 대한 확실한 인식과 전문 직업인으로서 자존감 및 차별화된 업 무 수행능력이 갖추어져야 할 것이다[1]. 이에 두 직군간의 업무를 재정립하고 간호조무사의 업무 한계를 제도적으로 재확립하는 것이 필요할 것이 
며, 향후에는 구강보건보조인력의 수행 업무현황과 업무의 타당성 및 효율성을 규명하는 연구를 통해 합리적인 구강보건인력 구조를 이루어 양질의 구 강보건을 제공해야 할 것이다.

\section{참고문헌}

1. 김은희(2004), 치과위생사와 간호조무사의 업무실 태 연구, 석사학위논문, 인제대학교 보건대학원, pp.1-39.

2. 건강보험심사평가원(2009), 건강보험심사통계지표 보고서, pp.1-10.

3. 안용순, 신성정, 정세환, 이영수, 임도선(2006), 치 과의원에서 근무하는 치과위생사와 간호조무사의 업무 및 이직현황 비교분석, 대한구강보건학회지, Vol.30(3);303-315.

4. 이병호(2011), 치과위생사의 건강증진행위와 직무 소진의 상관관계 분석, 보건의료산업학회지, Vol.5(3);111-121.

5. 김미형(1995), 치과위생사 활용방안에 관한 조사연 구, 광주보건대학 논문집, Vol.20;211-228.

6. 구강보건교재개발위원회(2010), 공중구강보건학, 고문사, pp.219-220.

7. 이은숙, 강현숙, 김영경외 12 인(2003), 치과위생학 개론 4 판, 고문사, pp.3-39.

8. 의료기사 등에 관한 법률 시행령법(일부개정 2011.4.28), 법률 제10608호 제2조, 법제처.

9. 간호조무사 및 의료유사업자에 관한 규칙(일부개 정2010.4.23.), 보건복지부령 제6호 제2조 1항, 법 제처.

10. 김영숙, 신민우(2008), 치과위생사의 업무 실태 및 비중에 관한 연구, 한국치위생교육학회지, Vol.8(3);161-173.

11. 정순희(1993), 치과위생사의 업무 실태 및 의식구
조에 관한 연구, 치아사랑 간행지, p.15.

12. 신승철, 조자원, 김동기, 임정희 외 18 인(2007), 치 과보조인력에 관한 연구보고, 단국대학교 치과대 학 예방치과, pp.1-16.

13. 한국보건의료인국가시험원(2000), 치과위생사 직 무분석, http://www.kuksiwon.or.kr/.

14. 박정란, 류정숙, 최부근 외 3인(2004), 치과위생사 의 업무 확장에 관한 조사연구, 대한치과위생사협 회, pp.131-138.

15. 임미희, 한수진, 정재연(2004), 치과위생사의 업무 및 업무분장에 관한 치과의사의 인식에 대한 연 구, 대한치과위생학회지, Vol.6(1);71-86.

16. 김지현, 김혜영, 이선경, 조영식, 박용덕(2008), 구 강보건인력의 현황 및 인력난 조사연구, 대한구강 보건학회지, Vol.32(4);540-550.

17. http://www.dentalnews.or.kr/news/search_resu lt.html.

18. 천대진, 이규환, 조자원(2010), 치과진료기관 근무 간호조무사의 업무에 관한 치과의사의 인식도, 대 한구강보건학회지, Vol.34(1);98-106.

19. 박지현, 김문숙, 조자원(2010), 치과위생사의 업무 범위에 관한 치과의사의 인식조사 연구, 대한구강 보건학회지, Vol.34(1);88-97.

20. 최명희(1992), 간호사와 간호조무사의 업무에 관 한 연구, 석사학위논문, 한양대학교 행정대학원, pp.1-42.

접수일자 2012년 7월 16일 심사일자 2012년 8월 1일 게재확정일자 2012년 12월 14일 